\title{
IDENTIFIKASI IKAN GENUS MYSTUS DENGAN PENDEKATAN GENETIK
}

\author{
Identification Of Mystus Fish With Genetic Approach \\ Taufik B. Pramono ${ }^{1,2}$, Diana Arfiati², Maheno S. Widodo², Uun Yanuhar $^{2}$ \\ ${ }^{1}$ PS Budidaya Perairan, FPIK, Unsoed, Purwokerto, 53123, Indonesia \\ ${ }^{2}$ Program PascaSarjana, FPIK, UB, Malang, 65145, Indonesia \\ *Korespondensi : tb1pram@yahoo.com
}

\begin{abstract}
ABSTRAK
Ikan-ikan dari Famili Bagridae di Indonesia mencapai 60 jenis dan salah satunya dari genus Msytus. Metode yang digunakan untuk identifikasi ikan yang sangat cepat dan akurat sangat diperlukan. DNA barcoding adalah teknik identifikasi baru dengan pendekatan molekular. Gen CO1 diamplifikasi dan produk PCR disekuensing serta dianalisis dengan menggunakan software bioinformatika. Pengeditan hasil sekuensing dan penentuan komposisi nukleotida dianalisis dengan software Mega5. Urutan DNA disejajarkan dengan ClustalW vers. 1.4. Sekuens dibandingkan dengan data GenBank menggunakan BLAST (Basic Local Aligment Search Tools) dan BOLDSystems. Pohon filogenetik dibuat dengan menggunakan metode Neighbor_Joining. Salah satu contoh identifikasi ikan dari genus Mystus yang telah dikonfirmasi adalah Mystus nigriceps menjadi Mystus singaringan.
\end{abstract}

Kata Kunci : Identifikasi, Mystus, DNA barcode

\begin{abstract}
The fish of the Bagridae Family in Indonesia reach until 60 species and one of them is from the genus Msytus. The method is used for fast and accurate species identification was needed. DNA barcoding was a new identification method with molecularly approach. The CO1 gene was amplified and PCR products were sequenced and analyzed using bioinformatics software. Editing of sequencing results and determining the nucleotide composition were analyzed with Mega5 software. The DNA sequence was aligned with ClustalW vers. 1.4. Sequences are compared with GenBank data using BLAST (Basic Local Aligment Search Tools) and BOLDSystems. Phylogenetic tree was made using Neighbor_Joining method. One example of the identification of fish from the confirmed Mystus genus is Mystus nigriceps being the Mystus singaringan.
\end{abstract}

Keywords : Identification, Mystus, DNA Barcoding

\section{PENDAHULUAN}

Ikan air tawar di Indonesia yang telah diidentifikasi sekitar 1218 spesies dari 84 famili termasuk 1172 spesies asli dari 79 famili dan 630 spesies bersifat endemik. Ikan dari Famili Bagridae teridentifikasi sebanyak 60 spesies. Uniknya, ikan dari Famili Bagridae tidak ditemukan daerah Wallacea dan Sahul, hanya ditemukan di Sundaland (Hubert et.al., 2015).

Ikan-ikan famili Bagridae juga ditemukan di DAS Serayu Jawa Tengah. Setijanto et.al. (1999) melaporkan bahwa terdapat tiga spesies ikan famili Bagridae di Sungai Serayu dan Mengaji yaitu Mystus gulio, mystus microcanthus dan Mystus nigriceps. Putro (2003) dan Pramono (2010) di Sungai Klawing yang 
masih merupakan DAS Serayu, masingmasing mendapatkan spesies ikan famili Bagridae lain yaitu ikan Baceman (Mystus nemurus) dan yaitu ikan Senggaringan (Mystus nigriceps). Penamaan spesies-spesies ikan dari Famili Bagridae yang telah ditemukan dan diteliti di DAS Serayu tersebut berdasarkan karakter morfologi yang mengacu pada Kotellat et.al. (1993).

Penamaan dan determinasi spesies yang benar sangat penting untuk melakukan kajian bioekologi dan kajian lainnya. Seiring dengan perkembangan biologi molekuler, telah ditemukan metode baru untuk identifikasi spesies berbasis DNA yang dikenal dengan DNA Barcoding (Floyd, et.al., 2002; Hebert et.al., 2003a; ). DNA barcoding membe-rikan kecepatan dan keakuratan dalam identifikasi spesies dengan fokus analisis pada segmen kecil dari mtDNA (Muchlisin et.al., 2013; Karim et.al., 2015). DNA barcoding dapat menjadi solusi krisis taksonomi (Meier et.al., 2006).

Penamaan spesies dari ikan Famili Bagridae utamanya ikan Seng-garingan (Mystus nigriceps) yang telah diteliti sebelumnya perlu diperjelas dengan pendekatan genetik menggunakan metode DNA Barcoding.

Penelitian ini bertujuan untuk mengkon-firmasi penamaan spesies ikan dari genus Mystus utamanya Mystus nigriceps secara genetik menggunakan marker gen CO1. Harapannya dapat dijadikan dasar dalam manajemen sumberdaya ikan dan konservasi serta budidayanya selanjutnya.

\section{METODE PENELITIAN}

\section{Ikan Uji}

Sejumlah 18 ekor ikan uji dikoleksi dari Sungai Klawing Kabupaten Purbalingga Provinsi Jawa Tengah pada Februari 2017 dengan bantuan nelayan setempat. Untuk keperluan idetinfikasi spesies diambil sebuah jaringan sirip ekor (caudal fin) dan disimpan dalam larutan etanol 95\%.

\section{Ekstraksi DNA, PCR, dan Sekuensing}

Ekstraksi DNA genom dari sampel menggunakan metode Quick DNA Tissue/Insect Miniprep Kit (Zymo Research). Gen CO1 diamplifikasi menggunakan pasangan primer universal LCO1490: 5'-ggtcaacaaatcataaagatattgg3' dan HCO2198: 5'-taaacttcagggtgacca aaaaatca-3' (Folmer et.al., 1994). Komposisi reaksi PCR $(25 \mu \mathrm{l})$, yaitu $12,5 \mu \mathrm{l}$ PCR Buffer (2x), 0,5 $\mu$ l primer forward $(10 \mathrm{pmol} / \mu \mathrm{l}), 0,5 \mu \mathrm{l}$ primer reverse $(10$ $\mathrm{pmol} / \mu \mathrm{l})$, KOD FX Neo $(1.0 \mathrm{U} / \mu \mathrm{l}), 1 \mu \mathrm{l}$ template DNA, dan $5 \mu \mathrm{l} \quad \mathrm{ddH}_{2} \mathrm{O}$. Amplifikasi dilakukan dalam mesin Toyobo KOD FX Neo Catalog No KFX201.

Reaksi Polimerase Chain Reaction (PCR) dilakukan dalam 35 siklus dengan parameter pre denaturasi awal suhu $95^{\circ} \mathrm{C} / 3$ menit, denaturasi $98^{\circ} \mathrm{C} / 10$ detik, annealing $50^{\circ} \mathrm{C} / 30$ detik, extention $68^{\circ} \mathrm{C} /$ 1 menit. Hasil PCR divi-sualisasi dengan elektroforesis gel agarosa $1 \%(\mathrm{~b} / \mathrm{v})$, dimurnikan meng-gunakan Shrimp Alkaline Phosphotase (Amersham Biosciences Corporation, Arlington Heights, Illinois, USA) dan Exonuclease (Amersham) (SAP/EXO). Sekuensing 2 arah (bi-directional) dila-kukan oleh First Base CO (Malaysia) menggunakan Big Dye $\odot$ terminator v3.1 cycle sequencing kit Applied Biosystem.

\section{Analisis Data}

Pengeditan hasil sekuensing dan penentuan komposisi nukleotida dianalisis dengan software Mega5 (Tamura et.al., 2011). Urutan DNA disejajarkan dengan ClustalW vers. 1.4 (Thompson $e t$ $a l .$, 1997). Sekuens dibandingkan dengan data GenBank menggunakan BLAST (Basic Local Aligment Search Tools) (Altschul et.al., 1997) dan BOLDSystems (Ratnasingham dan Hebert, 2007). Pohon filogenetik dibuat dengan menggunakan metode Neighbor Joining (Saitou dan Nei, 1987). 


\section{HASIL DAN PEMBAHASAN}

Hasil PCR menunjukkan gen CO1 teramplifikasi dengan panjang 697 bp (Gambar 1). Ukuran panjang amplifikasi hasil dalam penelitian ini sama dengan penelitian yang dilakukan Folmer et.al. (1994), yang memperoleh ukuran kurang lebih $700 \mathrm{bp}$.

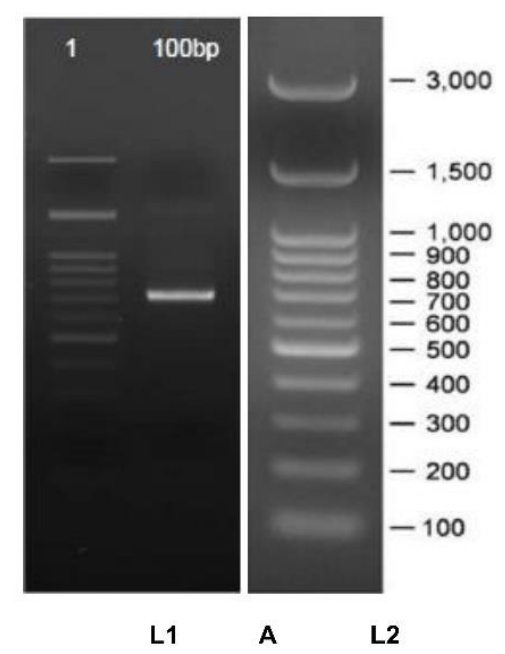

Gambar 1. Hasil amplifikasi gen CO1 sampel ikan uji dari Sungai Klawing dalam gel agarose $1 \%$. L1 adalah DNA Ladder dan A adalah sampel serta L2 adalah panjang garis gen (GeneRuler)

Sekuens yang diperoleh ini tidak ada gap, insersi atau delesi dan tidak memiliki stop kodon. Hal ini menunjukan bahwa sekuens ini merupakan gen struktural, COI (Gambar 2).
Homologi untuk menentukan identitas spesies dilakukan analisis BLAST (Gambar 3) dan DNA Barcoding menggunakan BOLD system (Gambar 4).

Adapun dari hasil BLAST dan BOLD system menunjukkan bahwa homologi sekuens sampel ikan uji memiliki kemiripan dengan ikan Mystus singaringan. Hasil BLAST menunjukan identitas atau tingkat kemiripan mencapai $99 \%$ dan hasil BOLD mencapai 99,84\%. Berdasarkan species page, BIN Page (Barcode Index Number), dan filogenetik dalam BOLD system dinyatakan bahwa sampel ikan uji ini adalah spesies ikan Mystus singaringan.

Hasil identifikasi spesies ikan dari Famili Bagridae dari Sungai Klawing Jawa Tengah yaitu yang dulunya Mystus nigriceps (Pramono, 2010) telah terkonfirmasi secara genetik dalam penelitian menggunakan metode DNA Barcoding menjadi Mystus singaringan.

Hasil identifikasi sampel uji (KLW PBG) secara genetik ini tidak terbantahkan adalah Mystus singaringan, kecuali ada spesies sangat mirip secara genetik namun hal tersebut sangat jarang terjadi. Secara taksonomi, merujuk pada BOLD system dan BLAST merupakan Phylum Chordata, Kelas Actinopterygii, Ordo Siluriformes, Famili Bagridae dan Genus Mystus serta speciesnya Mystus singaringan.

\section{ACAAAGACAT TGGCACCCTT TACCTAGTAT TCGGTGCCTG AGCCGGAATA GTCGGTACAG \\ 61 CCCTAAGCTT GCTGATTCGG GCAGAACTAG CCCAACCCGG TGCCCTTCTA GGCGACGACC \\ 121 AAATTTACAA TGTTATTGTA ACTGCTCATG CCTTCATTAT AATTTTCTTT ATAGTAATGC \\ 181 CAATCATGAT CGGAGGCTTC GGAAACTGAC TCGTGCCTCT AATAATTGGA GCACCAGACA \\ 241 TGGCCTTCCC ACGAATAAAT AATATAAGCT TCTGATTATT ACCCCCCTCG TTTCTATTAC \\ 301 TGTTAGCTTC CTCCGGAGTC GAAGCTGGTG CAGGTACAGG ATGAACTGTT TATCCACCCC \\ 361 TTGCCGGCAA TCTTGCACAC GCCGGGGCTT CAGTAGACCT AACAATCTTC TCCCTACACC \\ 421 TTGCAGGGGT ATCCTCCATT CTTGGAGCTA TTAATTTTAT TACAACTATT ATTAACATGA \\ 481 AACCTCCAGC CATCTCCCAA TACCAAACCC CCTTATTTGT ATGGGCTGTA CTAATTACAG \\ 541 CTGTACTACT ACTACTATCT CTTCCCGTTC TAGCTGCTGG TATCACCATG CTGCTAACAG \\ 601 ATCGAAATCT TAATACTACA TTTTTTGATC CCGCAGGAGG AGGAGATCCA ATTCTTTATC \\ 661 AACACTTATT CTGATTCTTC GGTCACCCTG AAGTGT}

Gambar 2. Hasil Sekuens sampel penelitian 


\begin{tabular}{|c|c|c|c|c|c|c|c|}
\hline & Description & $\begin{array}{c}\text { Max } \\
\text { score }\end{array}$ & $\begin{array}{l}\text { Total } \\
\text { score }\end{array}$ & $\begin{array}{l}\text { Query } \\
\text { cover }\end{array}$ & $\begin{array}{c}E \\
\text { value }\end{array}$ & Ident & Accession \\
\hline$\checkmark$ & Mystus singaringan voucher BIF 3741 cytochrome oxidase subunit 1 (COl) gene, partial cds: mitochondrial & 1106 & 1106 & $88 \%$ & 0.0 & $99 \%$ & $\underline{K} 6992660.1$ \\
\hline 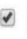 & Mystus singaringan voucher BIF 3660 cytochrome oxidase subunit 1 ( $\mathrm{CO}$ ) gene. partial cds: mitochondrial & 1103 & 1103 & $88 \%$ & 0.0 & $99 \%$ & KU692662.1 \\
\hline$\checkmark$ & Mystus singaringan voucher BIF 3662 cytochrome oxidase subunit 1 ( $\mathrm{CO}$ ) gene, partial cds: mitochondrial & 1103 & 1103 & $88 \%$ & 0.0 & $99 \%$ & KU692661.1 \\
\hline$\checkmark$ & Mystus singaringan voucher BIF 3661 cytochrome oxidase subunit 1 ( $\mathrm{COI}$ ) gene, partial cds: mitochondrial & 1077 & 1077 & $86 \%$ & 0.0 & $99 \%$ & KU692659.1 \\
\hline$\checkmark$ & Mystus bleekeri voucher MB-2001 cytochrome oxidase subunit I ( $\mathrm{CO}$ ) gene, partial cds: mitochondrial & 895 & 895 & $99 \%$ & 0.0 & $89 \%$ & KJ936764.1 \\
\hline$\checkmark$ & Mystus bleekeri voucher PUMNH 26/2014 cytochrome c oxidase subunit 1 (COl) gene, partial cds: mitochondrial & 874 & 874 & $97 \%$ & 0.0 & $89 \%$ & KX266834.1 \\
\hline 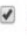 & Mystus cavasius mitochondrion, complete genome & 868 & 868 & $99 \%$ & 0.0 & $88 \%$ & KU870465.1 \\
\hline 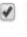 & Mystus vittatus mitochondrion, complete genome & 865 & 865 & $99 \%$ & 0.0 & $88 \%$ & KX177968.1 \\
\hline$\checkmark$ & Mystus bleekeri voucher DUZM118 cytochrome oxidase subunit I (col) gene, partial cds: mitochondrial & 859 & 859 & $97 \%$ & 0.0 & $88 \%$ & KT 364779.1 \\
\hline 1 & Mystus cavasius voucher DUZM119 cytochrome oxidase subunit I (COl) gene, partial cds: mitochondrial & 848 & 848 & $98 \%$ & 0.0 & $87 \%$ & KT762365.1 \\
\hline
\end{tabular}

Gambar 3. Hasil BLAST terhadap sekuens sampel penelitian

\section{BOLDSYSTEMS} DATABASES IDENTFICATION TAXONOMY WORKBENCH RESOURCES LOGIN Q

\begin{tabular}{|c|c|c|c|c|c|c|c|c|}
\hline \multicolumn{2}{|c|}{ Top 20 Matches } & \multirow[b]{2}{*}{ Order } & \multirow[b]{2}{*}{ Family } & \multirow[b]{2}{*}{ Genus } & \multirow[b]{2}{*}{ Species } & \multirow[b]{2}{*}{ Subspecies } & Display: & \multirow[t]{2}{*}{$\begin{array}{ll}\text { Top } 20 & \text { v }\end{array}$} \\
\hline Phylum & Class & & & & & & Similarity (\%) & \\
\hline Chordato & Actinopterygii & Siluriformes & Bagridae & Mystus & singaringan & & 99.84 & Published巴 \\
\hline Chordata & Actinopterygii & Siluriformes & Bagridae & Mystus & singaringan & & 99.84 & Published \\
\hline Chordata & Actinopterygii & Siluriformes & Bagridae & Mystus & singaringan & & 99.84 & Published tes \\
\hline Chordata & Actinopterygii & Siluriformes & Bagridae & Mystus & singaringan & & 99.83 & Published \\
\hline Chordata & Actinopterygii & Siluriformes & Bagridae & Mystus & singaringan & & 91.96 & Early-Release \\
\hline Chordata & Actinopterygii & Siluriformes & Bagridae & Mystus & singaringan & & 91.96 & Early-Release \\
\hline Chordata & Actinopterygii & Siluriformes & Bagridae & Mystus & singaringan & & 91.96 & Private \\
\hline Chordata & Actinopterygii & Siluriformes & Bagridae & Mystus & singaringan & & 91.96 & Private \\
\hline Chordata & Actinopterygii & Siluriformes & Bagridae & Mystus & singaringan & & 91.96 & Private \\
\hline Chordata & Actinopterygii & Siluriformes & Bagridae & Mystus & singaringan & & 91.96 & Private \\
\hline Chordata & Actinopterygii & Siluriformes & Bagridae & Mystus & singaringan & & 91.81 & Private \\
\hline Chordata & Actinopterygii & Siluriformes & Bagridae & Mystus & albolineatus & & 89.95 & Early-Release \\
\hline Chordata & Actinopterygii & Siluriformes & Bagridae & Mystus & albolineatus & & 89.95 & 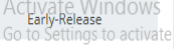 \\
\hline Chordata & Actinopterygii & Siluriformes & Bagridae & Mystus & albolineatus & & 89.8 & Early-Release \\
\hline
\end{tabular}

Gambar 4. Hasil BOLD System terhadap sekuens sampel penelitian 

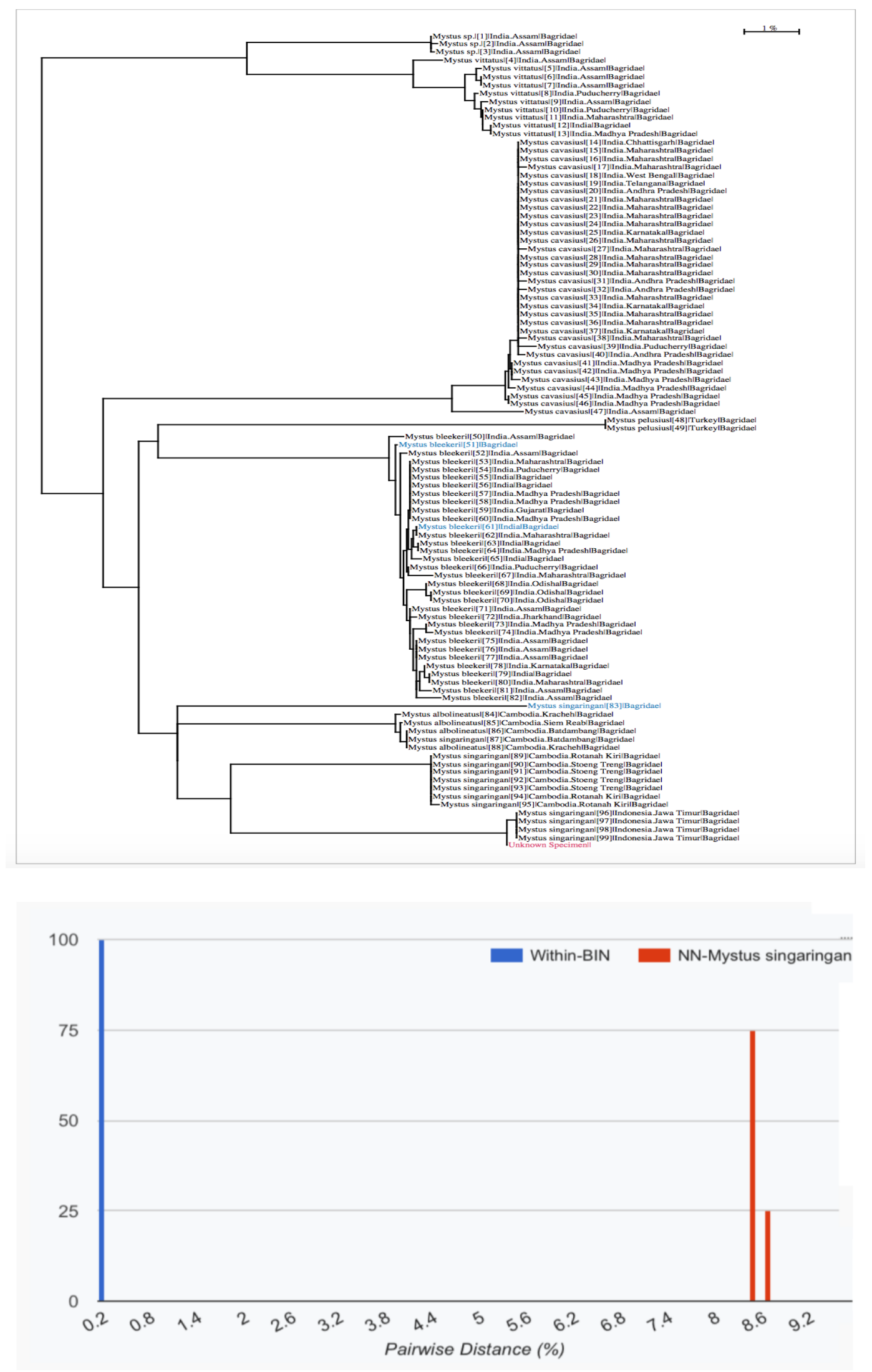

Gambar 5. Bukti kedekatan sekuens penelitian dengan M. singaringan, filogenetik (atas) dan distribusi jarak (bawah). Unknown speciment adalah sampel penelitian. 
Berdasarkan barcode index number (BIN) dalam BOLD system, secara morfologi (Gambar 6), jarak pasangan dan sekuens sampel ikan Mystus singaringan dalam penelitian ini masuk dalam satu klaster dengan ikan $M$. Singaringan yang berasal dari Kediri Jawa Timur (Hubert et.al., 2015). Nilai barcode index number memiliki arti sebagai sebuah kerangka online yang mengelompokan secara algoritma yang menghasilkan halaman web untuk setiap klaster. Karena klaster menunjukkan kecocokan tinggi dengan spesies, sehingga sistem ini dapat digunakan untuk verifikasi identitas spesies juga keragaman dokumen ketika informasi taksonomi (Ratnasingham dan Hebert, 2013).

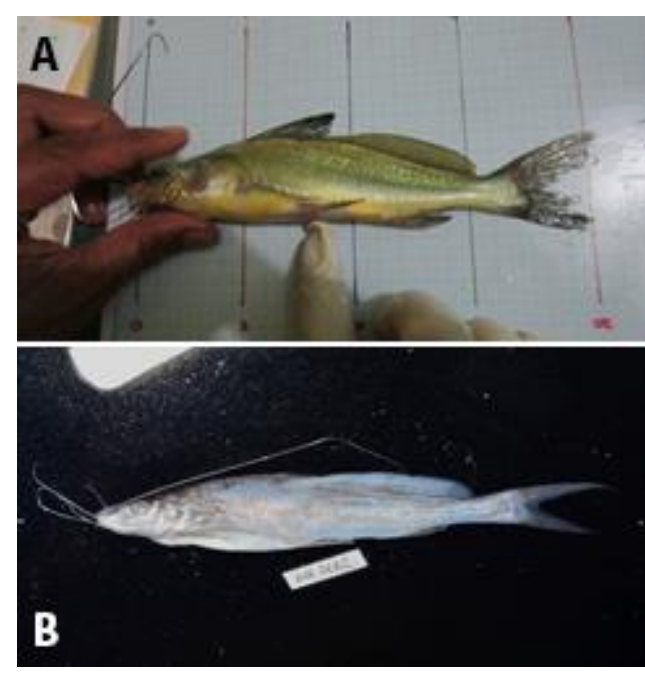

Gambar 6. (A) Ikan M. singaringan dari Sungai Klawing Jawa Tengah; (B) Ikan Mystus singaringan dari Kediri Jawa Timur.

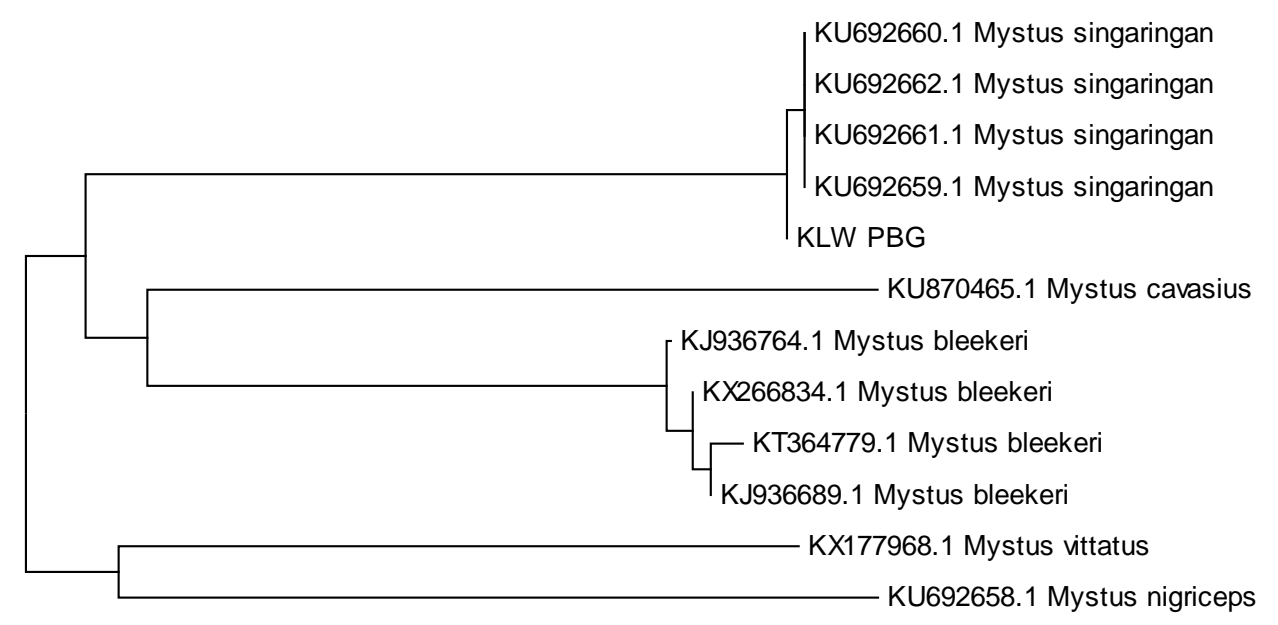

Gambar 7. Pohon Filogenetik

Kedekatan antara spesies yang akan diidentifikasi dan yang menjadi rujukan tidak terbukti dengan spesies terdahulu, Mystus nigriceps. Berdasarkan analisis filogenetik sekuens penelitian dengan kode KLW PBG dan sekuens genus yang sama diperoleh bahwa spesies penelitian ini lebih dekat pada Mystus singaringan (Gambar 7).
Kekerabatan antara Mystus singaringan dan $M$ nigirceps sangatlah jauh jika dilihat dari pohon filogenetik. Pohon filogenetik menggambarkan garis keturunan evolusi dari spesies, organisme atau dari satu nenek moyang berbeda (Hall, 2011). Berdasarkan pohon filogenetik yang dibuat dapat diketahui hubungan genetik antar spesies dalam satu populasi dan antar populasi. Filogeni berguna juga untuk mengorga-nisir 
pengetahuan keragaman biologis untuk klasifikasi struktural dan untuk memberikan wawasan ke dalam peris-tiwa yang terjadi selama evolusi (Taylor, 2014).

Beberapa penelitian identifikasi spesies ikan-ikan di perairan tawar dan laut di Indonesia juga dilakukan dengan menggunakan DNA Barcoding seperti yang dilakukan oleh Muchlisin et.al. (2013) di Danau Laut Tawar Aceh, Bulu Babi di Teluk Cendrawasih (Toha, et.al, 2015), Dahrudin et.al. (2016) di Pulau Jawa dan Bali, dan Hubert et.al. (2016) di Dataran Sunda, Wallacea dan Sahul. Penggunaan DNA barcoding dapat menjadi solusi krisis taksonomi (Meier et.al., 2006) dan perspektif baru dalam ekologi dan sistematika ikan (Hubert, et.al., 2008), manajemen sumberdaya ikan dan konservasi (Hubert et.al, 2016).

DNA barcoding memberikan kecepatan dan keakuratan dalam identifikasi spesies dengan fokus analisis pada segmen kecil dari mtDNA (Muchlisin et.al., 2013; Karim et.al., 2015). Pada eukariot, mtDNA terdiri dari molekul DNA rantai untai ganda yang berukuran 15-20 kb (Hurst dan Jiggiins, (2005). DNA barcoding bertujuan untuk menyediakan metode yang kompeten untuk identifikasi hingga tingkat spesies dengan menggunakan penanda molekuler yang merupakan turunan dari lima wilayah gen cytochrome c oxidase I (COI) (Hubert, et.al., 2008). Penggunaan Barcode ini sangat memungkinkan untuk mengidentifikasi spesies yang berbeda dengan variasi antar spesies yang cukup banyak dan variasi intra spesifik yang rendah (Yao, et.al., 2010).

Menurut Hurst dan Jiggiins, (2005), DNA barcoding memiliki dua kelebihan yaitu, pertama bersifat haploid dan dan memiliki wilayah yang sangat lestari (conserved) sehingga fragmen COI secara teknis mudah mengamplifikasi tanpa cloning pada ragam spesies. Kedua, mitokondria memiliki ukuran populasi yang efektif kira-kira seperempat dari penanda dan pada hewan ratarata memiliki tingkat evolusioner yang tinggi. Oleh karena itu memiliki tingkat deklarasi yang tinggi pula. Spesies yang relatif dekat pun dapat dibedakan menggunakan sekuens yang pendek.

Kelebihan lain DNA barcoding adalah dapat mengidentifikasi spesies yang sulit dibedakan secara morfologi (Hebert et.al., 2004) dan menggunakan sampel jaringan yang sangat sedikit sehingga tidak harus mematikan hewannya. Namun demikian, metode ini sangat tergantung pada tersedia tidaknya data sekuens (reference sequences) yang akurat sebagai pembanding (Stoeckle, 2003). Hasil DNA Barcoding dapat digunakan sebagai studi yang lebih luas misalnya studi filogenetik (Erickson dan Driskell, 2012; Huang et.al., 2016), filogeografi (Yu, 2014) dan genetika populasi (Draft et.al., 2010) serta, variasi genetik untuk stabilitas dan ketahanan populasi.

\section{KESIMPULAN}

Analisis genetik berdasarkan fragmen gen CO1 menunjukkan bahwa sampel penelitian dari Sungai Klawing Jawa Tengah merupakan spesies Mystus singaringan. Penelitian selanjutnya dapat dilakukan mengkaji keragaman dan struktur genetik.

\section{DAFTAR PUSTAKA}

Altschul, S.F., Madden T.L., Schaffer A.A., Zhang J., Zhang Z., Miller W., Lipman D.J. 1997. Gapped BLAST and PSI-BLAST : A New Generation of Protein Database Search Program. Nucleic Acid Research $25: 3389-3402$.

Dahruddin, H., Hutama A., Busson F., Sauri S., Hanner R., Keith P., Hadiaty R.K., Hubert N. 2016. Revisiting the Ictyodiversity of Java and Bali through DNA Barocdes : Taxonomic Coverage, Identification Accuray, Cryptic Diversity and Identification of Exotic Species. Molecular Ecology Resources : 1-12.

Draft, K.J., Pauls, S.U., Darrow, K., Miller S.C., Hebert, P.D., Helgen, 
L.E., Novotny, $\mathrm{V}$ and Weiblen, G.D. 2010. Population Genetics of Ecological Communities With DNA Barcodes : An Example From New Guinea Lepidoptera. PNAS 107 (1) : 5401-5046.

Erickson, D.L., and Driskell, A.C. 2012. Construction and Analysis of Phylogenetik Trees Using DNA Barcode Data. Methods Mol. Biol 85 (8) : 395-408.

Floyd, R., Abebe E., Papert A., and Blaxter M. 2002. Molecular barcodes for soil nematode idetification. Molecular Ecology 11 (4) : 839-850.

Folmer O., Black M., Hoeh W., Lutz R., and Vrijenhoek R. 1994. DNA primers for amplification of mitochondrial cytochrome c oxidase sub unit I from diverse metazoan invertebrates. Molecular Marine Biology and Biotechnology 3(5) : 294-299.

Frankham, R. 1996. Relationship of Genetic Variation to Population Size In Wildlife. Conservation Biology 10 (6) : 1500-1508.

Hebert, P. D.N., Cywinska A., Ball S.L., and de Ward J.R. 2003a. Biological Identifications Through DNA Barcodes. Proceeding Royal Society Part B. Biological Sciences 270 (1512) : 313-322.

Hebert, P.D.N., Penton, E.H., Burns, J.M., Janzen, D.H., and Hallwachs, W. 2004. Ten Species In One : DNA Barcoding Reveals Cryptic Species In The Neotropical Skipper Butterfly Astraptes fulgerator. PNAS 101 (41) : 14812-14817.

Huang, Z., Yang, C., and Ke, D. 2016. DNA Barcoding and Phylogenetic Relationships In Anatidae. Mitochondrial DNA 27 (2) : 10421044.
Hubert, N., Kadarusman., A. Wibowo., F. Busson., D. Caruso., S. Sulandari., N. Nafiqoh., L. Pouyaud., L. Ruber., J.C. Avare., F. Herder., R. Hanner., P. Keith. R.K. Hadiaty. 2015. DNA Barcoding Indonesian Freshwater Fishes : Challenges and Prospects. DNA Barcodes 3 : 144-169.

Hughes, A.R., Inouye, B.D., Johnson, M.T.J., Underwood, N. And Vellend, M. 2008. Ecological Consequences of Genetic Diversity. Ecology Letters 11 : 609-623.

Hurst, G. D. D. And Jiggins, F.M. 2005. Problems with Mitochondrial DNA as a Marker In Population, Phylogeographics and Phylogenetic Studies : The Effects of Inherited Symbions. Proc R Soc B 272 : 1525-15234.

Karim, A., Iqbal, A., Akhtar, R., Rizwan, M., Amar, A., Qamar, U., and Jahan, S. 2015. Barcoding of Fresh Water Fishes From Pakistan. Mitochondrial DNA : 14.

Kottelat, M., A.J. Whetten., Sri Nuraini K., dan Sutikna W. 1993. Freshwater Fishes of Western Indonesia and Sulawesi. CV Java Books. Jakarta. 293 p.

Meier, R., Shiyang K., Vaidya G. And Peter K.L.N. 2006. DNA Barcoding and Taxonomy In Diptera. A Tale of High Intraspesific Variability and Low Identification Success. System Bio. 55 : 715-728.

Muchlisin, Z. A., Thomy Z., Fadli N., Sarong, M.A., and Siti-Azizah, M.N. 2013. DNA Barcoding Of Freswater Fishes From Lake Laut Tawar, Aceh Province, Indonesia. Acta Ichtyiologica Et Piscatoria 43 (1) : 21-29.

Pramono, T. B. 2010. Profil Reproduksi Ikan Senggaringan (Mystus 
nigriceps) : Dasar Pengembangan Domestikasi dan Budidaya. Tesis. Program Pascasarjana Institut Pertanian Bogor. Bogor.

Pratasik, S.B., Marsoedi., Arfiati D., and Setyohadi D. 2016. Mitochondrial CO1 genetic mareker-based species diversity of cuttlefish (Chepalopod : Molusk) in Manado Bay and Lembeh Strait, Notrh Sulawesi, Indonesia. $A A C L$ Bioflux 9 : 1345-1354.

Putro, S. S. 2003. Ekologi Ikan Baceman (Mystus nemurus) Di Sungai Klawing Kabupaten Purbalingga dan Beberapa faktor yang Berkaitan dengan Domestikasinya. Tesis Magister Sains Ilmu Lingkungan. Program Pascasarjana Universitas Jenderal Soedirman. Purwokerto.

Ratnasingham S., and Hebert P.D.N. 2007. BOLD : The Barcode of Life Data system (http://www.barco dinglife.org). Molecular Ecology Notes 7 (3) : 355-364.

Saitou N., Nei M. 1987. The neighborjoining methd : a new method for reconstructing phylogenetic tress. Molecular Biology and Evolution. 4 (4) : 406-425.

Setijanto., Aryani, E., dan Proklamasiwati. 1999. Distribusi Altitudinal Ikan Sungai : Informasi Dasar Penggunaanya sebagai Indikator Kualitas Air dan Usaha Budidayanya. Laporan Hasil Penelitian. Fakultas Biologi Unsoed. Tidak Dipublikasikan.

Stoeckle, M. 2003. Taxonomy, DNA and The Barcode of Life. BioScience 53 : 2-3.

Tamura, K., Peterson, D., Peterson, N., Stecher, G., Nei, M., and Kumar, S. 2011. Mega5 : Molecular Evolutionary Genetics Analysis Using Maximum Likelihood, Evo- lutionary Distance and Maximum Parsimony Methods. Mol. Biol. Evol., 1-9.

Taylor, D. R. And Aarssen, L. W. 1988. An Interpratation of Phenotupic Plasticity In Agropyron Repens (Gramineae). American Journal of Botany 75 (3) : 401-413.

Taylor, A.L. 2014. Population Structure and Phylogeography of Octopus cyanea and Lethrinus Species In The South-Western Indian Ocean. Thesis. Unpublished.

Thompson, J.D., Gibson, T.J., Plewniak, F., Jeanmougin, F. And Higgins, D.G. 1997. The ClustalIX Windows Interface : Felxible Strategies for multiple sequence alignment aided by quality analysis tools. Nucleic Acids Research 25 :4876-4882.

Toha, A.H.A., Sumitro, S.B., Widodo., and Hakim L. 2015. Color Diversity and Distribution of Sea Urchin Tripneustes gratilla in Cendrawasih Bay Ecoregion of Papua, Indonesia. Egyptian Journal of Aquatic Research 41 : 273-278.

Yao, H., Song J., Liu C., Luo K., Han., Li Y., and Pang. 2010. Use of ITS2 Region as The Universal DNA Barcode for Plants and Animals. PloS One 5 :e131102. doi: 10.1371/jounal.pone.0013102

Yu, S. S. 2014. DNA Barcoding and Phylogeographic Analysis of Nippoacmea Limpets (Gastropoda : Lottidae) In China. Journal Mollusca Stud. 80 (4) : 420-429. 
